Smith, D.C., et al., 2000

ODP Technical Note 28

\title{
Methods for QUANTifying Potential Microbial CONTAMINATION DURING DEEP OCEAN CORING ${ }^{1,2}$
}

\author{
David C. Smith, ${ }^{3}$ Arthur J. Spivack, ${ }^{4}$ Martin R. Fisk, ${ }^{5}$ \\ Shelley A. Haveman, ${ }^{6}$ Hubert Staudigel, ${ }^{7}$ and \\ the Leg 185 Shipboard Scientific Party ${ }^{8}$
}

\section{INTRODUCTION}

The Ocean Drilling Program (ODP) is committed to deep-biosphere research and has constructed a new microbiological laboratory on board the JOIDES Resolution. The use of the JOIDES Resolution as a platform for deep-biosphere research requires that the recovered cores are suitable for microbiological study. The major concern is whether microbes from the drilling fluid are introduced into the recovered core material during coring. Therefore, it is critical to verify whether recovered cores are contaminated. Here we present details of two tracer methods used to quantify the amount of contamination. These methods were modified from land-based drilling operations for use on the JOIDES Resolution (see review by Griffin et al., 1997). Tracer experiments were first conducted during ODP Leg 185 (Plank, Ludden, Escutia, et al., in press) and involve the delivery of both chemical and particulate tracers during drilling and their quantification in the ODP cores. These tracers were introduced while drilling unconsolidated sediments using the advanced hydraulic piston corer (APC), sedimentary rock using the extended core barrel and rotary core barrel (RCB), and igneous rock using the RCB and diamond core barrel. This technical note presents details on the characteristics, preparation, and delivery of the tracers and their quantification in cores. Suggestions are made regarding sample handling with the goal of minimizing sample contamination. It is strongly recommended that these contamination tests be routinely conducted when coring for microbiological studies.
${ }^{1}$ Smith, D.C., Spivack, A.J., Fisk, M.R., Haveman, S.A., Staudigel, H., and the Leg 185 Shipboard Scientific Party, 2000. Methods for quantifying potential microbial contamination during deep ocean coring. ODP Tech. Note, 28 [Online]. Available from World Wide Web: <http://www-odp. tamu.edu/publications/tnotes/tn28/ INDEX.HTM>. [Cited YYYY-MM-DD] ${ }^{2}$ See Disclaimer, p. 12.

${ }^{3}$ Graduate School of Oceanography, University of Rhode Island, Narragansett RI 02882, USA. dcsmith@gsosun1.gso.uri.edu ${ }^{4}$ Center for Marine Science Research, University of North Carolina, Wilmington NC 28403, USA. ${ }^{5}$ College of Ocean and Atmospheric Sciences, Oregon State University, Corvallis OR 97331, USA.

${ }^{6}$ Department of Cell and Molecular Biology, Göteborg University, Göteborg SE-40530, Sweden.

${ }^{7}$ Scripps Institution of Oceanography, University of California, San Diego, La Jolla CA 92093, USA.

${ }^{8}$ See the Leg 185 Initial Reports volume. 


\section{MATERIALS AND METHODS}

\section{Chemical Tracer: Perfluorocarbon}

\section{Characteristics}

Perfluorocarbon tracers (PFT) have been used extensively in landbased drilling applications (Senum and Dietz, 1991; Russell et al. 1992; McKinley and Colwell, 1996) because they are inert and can be detected with high sensitivity. Perfluoro(methylcyclohexane) is the tracer that has been tested on the JOIDES Resolution. This perfluorocarbon (Aldrich 30293-7) has a molecular weight of 350.05 , a boiling point of $76^{\circ} \mathrm{C}$, and a density of $1.76 \mathrm{~g} / \mathrm{mL}$. Its solubility is $1 \mathrm{mg} / \mathrm{L}$ in water and is $10 \mathrm{~g} / \mathrm{L}$ in methanol (Colwell et al., 1992). The low solubility in water facilitates gas phase partitioning and quantitative headspace analysis.

\section{Preparation and Delivery}

The stock PFT is shipped in sealed ampoules, and it is not necessary to dilute it prior to use. Because the PFT is volatile and can be detected at extremely low concentrations, it is necessary to open the ampoules and transfer the PFT to the carboy used for delivery in a ventilated area well away from the core handling and PFT detection areas. Gloves should be worn during this process and discarded afterward. It is recommended that this transfer be performed on the helicopter deck while the JOIDES Resolution is under way and that all materials that may have been in contact with the PFT be disposed of immediately. These precautions will minimize the probability of obtaining false positives when analyzing core material.

The PFT is introduced into the stream of drilling fluid at a rate calculated to achieve a nominal final concentration of $1 \mathrm{mg} / \mathrm{L}$. The injection rate is controlled with a single-piston high performance liquid chromatography (HPLC) pump (Alltech model 301), which pumps the PFT from a polypropylene carboy into the drilling mud stream through a valve on the low-pressure side of mud charge pump No. 2 (Fig. F1). It is important that the carboy is secured. An additional HPLC pump connected to mud charge pump No. 1 allows the delivery of the tracer from both mud pumps. The time needed for the tracer to reach the bit is dependent on both the pipe length and the pumping rate of the drilling fluid and can be determined using the data in Table T1. Pumping of the tracer must be started early enough to allow it to reach the bit before coring begins. The pumping rate of the mud pump typically varies from 20 to 95 strokes/min (392-1862 L/min) and is controlled by the driller. PFT injection rates are adjusted to the mud pump output to maintain the $1 \mathrm{mg} / \mathrm{L}$ concentration in the entire drill string (Table T1). Currently, the PFT injection rate is controlled manually. Plans to control the PFT injection rate from the drillers' shack are under way.

\section{Collection of Samples}

\section{Sediments}

Unconsolidated sediment is sampled on the catwalk immediately after cores are retrieved. After the core liner is cut, the sediment core should be broken by pulling the sections apart instead of using the usual procedure of cutting the sections apart with a knife. This will ensure that the tracer is not dragged through the core with the knife. Two
F1. PFT delivery system, p. 13.

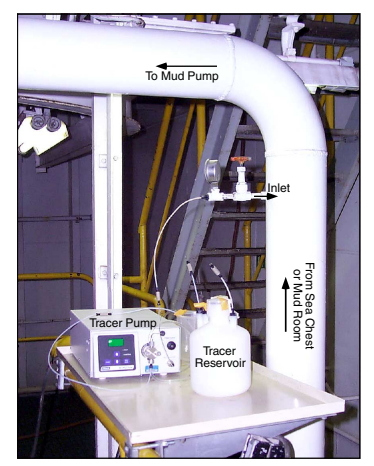

T1. Calculation chart for travel time and HPLC pumping rate, p. 18. 
plugs $\left(\sim 3 \mathrm{~cm}^{3}\right.$ each) from the bottom end of each section are taken with 5 -mL syringes that have been modified by cutting off the luer-lock end. New syringes are used for each sample. One sample is taken from the outer edge along the core liner and the other from near the center of the core. The samples are immediately extruded into 20-mL-capacity headspace vials (Hewlett Packard \#5182-0837) and sealed with gas-tight caps containing septa. The sample from the outer edge is used to confirm the successful delivery of the tracer, whereas the interior sample is used to quantify the intrusion of drill water into the core.

If the sediment is too hard to sample with a syringe, the exterior of the core must first be pared away using a hammer, chisel, and tongs. To prevent contamination of the interior while paring, the tools should be passed through the flame of a torch to remove any PFT. This procedure should be done on a new sheet of aluminum foil to prevent cross contamination between samples. Samples from the exterior and interior of the core are placed in headspace vials and sealed. Because the exterior of the core liner is coated with drilling fluid, contact with the liner is to be avoided while collecting core samples for PFT analysis.

\section{Igneous Rock}

Immediately after the core liner is split in half in the core lab, pieces of the core are chosen for PFT analysis. To confirm that the PFT reached the core, several small pieces of rock are placed directly into the headspace vials (ID $=19 \mathrm{~mm}$; height $=75 \mathrm{~mm}$ ) and immediately sealed. Alternatively, a cotton swab can be used to wipe the interior of the core liner and then placed in a headspace vial and sealed.

Ideally, the PFT is removed from the surface of the rock prior to sampling the interior. This will prevent the transfer of the tracer into the interior during sample preparation. This can be accomplished by rinsing the exterior with water or methanol and then drying it under a flame. Alternatively, the rock can be dried directly under a flame without rinsing. The piece is held with tongs under the flame from a handheld propane torch until it appears dry. Experiments conducted during Leg 185 using all three methods showed that drying the surface of the rock with a flame was the best method. There is a concern that this may compromise the usefulness of the sample for subsequent microbiological samples because of the heat and/or desiccation.

After removing the PFT from the exterior, pieces from the interior of the rock are obtained by paring away the exterior using a hammer and chisel while the rock is held on a sheet of aluminum foil. This may be accomplished more effectively using the hydraulic rock splitter. Tongs are used to move the rock onto new sheets of aluminum foil. After each paring, the tools are cleaned of PFTs by passing the tools through the flame of the torch, and the rock pieces are placed on new foil sheets. When the entire exterior of the rock is removed, the residual rock (interior) is placed in a percussion mortar and crushed. Aliquots of the crushed rock are then placed in headspace vials and sealed.

\section{Perfluorocarbon Analysis}

A Hewlett Packard 8059 gas chromatograph (GC) with an electron capture detector (HP G1223A) is used to quantify the PFT in the samples. The GC is equipped with an HP-PLOT $\mathrm{Al}_{2} \mathrm{O}_{3}$ " $\mathrm{M}$ " deactivation column (length $=15 \mathrm{~m}$; ID $=0.53 \mathrm{~mm}$; coating thickness $=15 \mu \mathrm{m}$ ), and nitrogen is used as the carrier gas. Hewlett Packard ChemStation software (Rev. A.05.02 [273]) is used to control the GC, including acquisition of chromatographs and peak area integration. The parameters of 
the runs were modified from Colwell et al. (1992). The injector temperature is $180^{\circ} \mathrm{C}$, and the initial oven temperature is $120^{\circ} \mathrm{C}$. The oven temperature is ramped upward immediately after injection at a rate of $20^{\circ} \mathrm{C} / \mathrm{min}$ to a final temperature of $150^{\circ} \mathrm{C}$ and held for $3 \mathrm{~min}$. This results in a total run time of 4.5 min with the PFT peak eluting at $~ 2.7$ min. The injector pressure is set at $3.0 \mathrm{psi}$, and the flow rate is $9.4 \mathrm{~mL} /$ min. The gas stream is not split before it reaches the detector. Samples, standards, and blanks are injected manually using Hamilton gas-tight syringes $(50,500$, and $5,000 \mu \mathrm{L})$. To minimize adsorption of the PFT on the interior surface of the syringe, the syringe is heated to $70^{\circ} \mathrm{C}$ prior to injection.

\section{Calibration}

Perfluoro(methylcyclohexane) is diluted in methanol to $10^{-1}, 10^{-3}$, $10^{-5}, 10^{-7}$, and $10^{-9} \mathrm{vol}: \mathrm{vol}$ in headspace vials to use as standards. These vials are immediately sealed to minimize loss of the PFT by volatilization. A $10-\mu \mathrm{L}$ aliquot of each solution in the dilution series is added to separate headspace vials and sealed. These vials are heated at $70^{\circ} \mathrm{C}$ in an oven to volatilize the PFT. Either 5 or $0.5 \mathrm{~mL}$ of the headspace gas is withdrawn with a heated $\left(70^{\circ} \mathrm{C}\right)$ gas-tight syringe and injected into the GC. The resultant signal is expanded in the vertical scale, and the perfluorocarbon peak is chosen manually. A standard curve is constructed using the peak area vs. PFT injected. Measured peak areas are linear with PFT headspace abundance over four orders of magnitude (Fig. F2). Based on duplicate analysis of standards, the relative measurement error is $20 \%(\sigma)$ and the detection limit is $\sim 6 \times 10^{-12} \mathrm{~g}$ PFT. This is equivalent to $0.006 \mu \mathrm{L}$ of drilling fluid when the PFT concentration in the drilling fluid is $1 \mathrm{mg} / \mathrm{L}$. Further details on calibrating the GC are presented in "Appendix A," p. 9.

\section{Sediment and Igneous Rock}

The headspace vials containing the samples, (sediment, whole rock, or crushed rock) and the gas-tight syringes are heated to $70^{\circ} \mathrm{C}$ in an oven. Five $\mathrm{mL}$ of headspace gas is injected into the GC. The signal is expanded in the vertical scale, and the perfluorocarbon peak is chosen manually based on the elution time of the standard. The peak area is integrated and converted to the amount of PFT using the values from the standard curve. The amount of sample is determined by weighing each vial and subtracting the weight of an empty vial. The total headspace volume is calculated by subtracting the volume of sample from the total volume of the vial. The total tracer concentration in the sample is corrected to account for the fraction of the headspace that is injected. The amount of drilling fluid present in the sample is calculated assuming that the tracer was present at $1 \mathrm{mg} / \mathrm{L}$ (or the final concentration of PFT if it is known from the injection and pumping rates to deviate from $1 \mathrm{mg} / \mathrm{L}$ ) (see “Appendix B," p. 10).

\section{Blanks}

Procedural blanks are analyzed to determine the instrumental and procedural backgrounds. These blanks consist of 5-mL injections of air collected in the gas-tight syringe from outside the laboratory or headspace gas from empty vials prepared at the same time and location the samples are taken.
F2. Plot of peak area vs. quantity of PFT, p. 14.

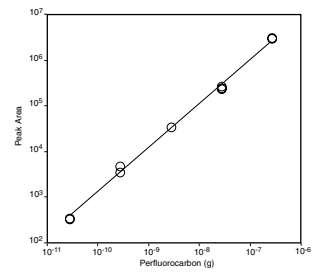




\section{Particulate Tracer: Fluorescent Microspheres}

\section{Characteristics}

Fluorescent microspheres of similar size to the indigenous microorganisms $(0.5-1.0 \mu \mathrm{m})$ have successfully been used in drilling operations (Harvey et al., 1989). Yellow-green fluorescent (458 $\mathrm{nm}$ excitation, $540 \mathrm{~nm}$ emission) microspheres $0.518( \pm 0.01) \mu \mathrm{m}$ in diameter (Fluoresbrite Carboxylate Microspheres; Polysciences Inc. \#15700) are used as a particulate tracer. These microspheres appear bright green when observed by epifluorescence microscopy using a blue filter set (Zeiss filter set 09 or 10) (Fig. F3).

\section{Preparation and Delivery}

The desired concentration of microspheres at the point of drilling is $\sim 10^{10}$ spheres $/ \mathrm{mL}$. To achieve this concentration, $2 \mathrm{~mL}$ of the microsphere suspension $\left(3.78 \times 10^{11}\right.$ spheres $\left./ \mathrm{mL}\right)$ is diluted to $40 \mathrm{~mL}$ with distilled water, and this solution is placed in an ultrasonic bath to disrupt aggregates. The microsphere suspension is placed in a plastic bag (Whirl-Pak; Nasco Inc.) and heat sealed.

A spacer with a channel to accommodate the top of the Whirl-Pak bag was machined to fit inside a core-catcher sleeve (Fig. F4A). The wire bail of the bag is taped into the groove in the brass spacer (Fig. F4B). The bag is draped over the core-catcher body and taped along the edges (Fig. F4C). The entire assembly is shown in Figure F4D. During APC drilling, the core barrel is lowered on a wireline, whereas the core barrel is allowed to free fall in the drill string from the drill floor to the bottom of the hole during RCB coring.

\section{Collection of Samples}

\section{Sediments}

As with the PFT samples (above), after the core liner is cut on the catwalk, the sediment core should be broken apart rather than cut so that the microspheres are not dragged through the core with the knife. While the core is still on the catwalk, toothpicks are used to collect small sediment samples from the bottom of core sections. If the cores are cut instead of broken, samples are retrieved from the interior of the core by boring into the core with successive toothpicks, using each only once. Sediment from the toothpick is removed from the toothpick by washing in $0.5 \mathrm{~mL}$ of distilled water. This can be done in either microcentrifuge tubes or in the wells of microplates. From each section that will be used for microbiological analysis, a sample is taken adjacent to the interior of the core liner, from the center of the core, and/or midway between the interior and the exterior of the core.

\section{Igneous Rock}

After splitting the core liner in the core lab, rock pieces are selected to determine the presence or absence of fluorescent microspheres. The surface of the rock is washed with distilled water, and the rinse is collected and examined with epifluorescence microscopy to verify the successful delivery of the microspheres. Samples that will be used for microbiological assays must first have the exterior pared away as with the perfluorocarbon tracer (above). After paring the exterior, the interior of the rock is crushed in a percussion mortar. Distilled water is
F3. Seawater sample containing bacteria and microspheres, p. 15.

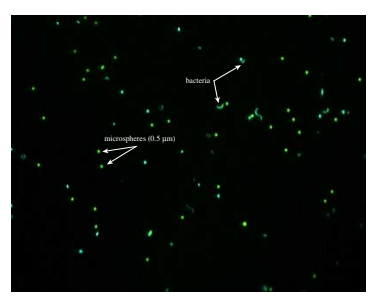

F4. Fluorescent microsphere delivery system, p. 16.

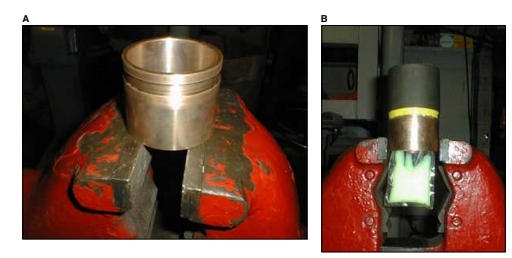


D.C. SMITH ET AL.

Tracer Tests For MiCrobiological STUdies

added to subsamples of this material in preparation for examination with the epifluorescence microscope (below).

\section{Quantification of Microspheres}

Fluorescent microspheres are quantified using a Zeiss Axiophot epifluorescence microscope outfitted with a mercury lamp (HBO 100W), a blue filter set, and a 100× Plan-NEOFLUAR oil-immersion objective. Nonfluorescent immersion oil is used for all observations (see "Appen$\operatorname{dix}$ C," p. 11).

\section{Sediments and Igneous Rock}

Aliquots $(50 \mu \mathrm{L})$ of the sediment slurry or the crushed rock are filtered onto black, $13-\mathrm{mm}$-diameter polycarbonate filters $(0.2-\mu \mathrm{m}$ pore size) in a filtration tower. The filters are then mounted on microscope slides with a drop of nonfluorescent immersion oil and covered with a cover slip. The microspheres on the filter are then counted using the epifluorescence microscope. Microsphere abundance on the filters is determined by averaging the total number seen in at least 20 randomly selected fields of view and normalizing to the area of the field of view, area of the filter used, and the volume of the sediment slurry that was filtered. The usable area of the filter is measured with calipers, and the area of the field of view is calibrated with a stage micrometer. It is critical that the filter tower used for the filter preparation is carefully cleaned of microspheres between samples to avoid cross contamination. If the amount of sample material is not weighed, the results are reported as spheres per milliliter of sediment suspension. If the material is weighed prior to preparing the filter, the results are reported as microspheres per gram of sample. The sediment sample adjacent to the core liner is used to verify the successful delivery of the microspheres in those cores, whereas filters prepared from the wash water are used for the igneous samples.

Thin sections prepared from the rocks can be examined for the presence of fluorescent microspheres by viewing with epifluorescence microscopy. A drop of nonfluorescent immersion oil is placed directly on top of the thin section, which is then examined with the epifluorescence microscope.

\section{CONCLUSIONS}

Both types of contamination tests presented here should be conducted when drilling for samples that will be used for microbiological studies. The PFT analysis is very rapid and can be used to screen samples for potential contamination before time and supplies are expended on samples. It is important to note that the absence of a tracer in the interior of a core has little meaning if the successful delivery of the tracer is not confirmed. Therefore, it is necessary to confirm the successful delivery of the tracer with each sample as outlined above.

We were able to detect as little as $6 \times 10^{-12} \mathrm{~g}$ of PFT. Higher sensitivity may possibly be achieved by using a smaller bore column on the GC. This should increase resolution and improve the signal-to-noise ratio. The use of a less volatile PFT may also improve the reliability of the method as an indicator of microbial contamination. 
D.C. SMith et AL.

Tracer TeStS For Microbiological STUdies

7

Results from the PFT experiments during Leg 185 suggest that the intrusion of drilling fluid is on the order of nanoliters per gram of core material (Smith et al., in press). Bacterial abundance in surface seawater is typically in the range of $0.1-1.0 \times 10^{9} / \mathrm{L}$. Our experience with differen coring and formations suggests that the intrusion of drilling fluid may account for at most, 1-10 bacteria/g of core material. Microspheres were never detected in the interior of APC-cored unconsolidated cedimints or RCB-cored consolidated sediment or igneous rock. Together, these results indicate that cores recovered on the JOIDES Resolution are suited for deep-biosphere research. Microspheres were seen in the interios of thin sections prepared from igneous samples. This indicates that postrecovery processing can be a source of contamination.

ACKNOWLEDGMENTS

We thank Bill Lee and Mark Robinson for designing and implementing the microsphere delivery system. In addition, we thank the entire technical staff of Leg 185, especially Anne Pimmel and Erik Moortgat, for assistance with the gas chromatograph, Roy Davis for assistance with the epifluorescence microscope, and John Pretorius, Peter Pratorus, Patrick Riley, and Matt O'Regan for making the laboratory van functional. We especially thank Kate Moran for facilitating the implementation of this study. 


\section{REFERENCES}

Colwell, F.S., Stormberg, G.J., Phelps, T.J., Birnbaum, S.A., McKinley, J., Rawson, S.A., Veverla, C., Goodwin, S., Long, P.E., Russell, B.F., Garland, T., Thompson, D., Skinner, P., and Grover, S,. 1992. Innovative techniques for collection of saturated and unsaturated subsurface basalts and sediments for microbiological characterization. J. Microbiol. Meth., 15:279-292.

Griffin, W.T., Phelps, T.J., Colwell, F.S., and Fredrickson, J.K., 1997. Methods for obtaining deep subsurface microbiological samples by drilling. In Amy, P.S., and Haldeman, D.L. (Eds.), The Microbiology of the Terrestrial and Deep Subsurface, Boca Raton (CRC Press, Lewis Publishers), 23-43.

Harvey, R.W., George, L.H., Smith, R.L., and LeBlanc, D.R., 1989. Transport of microspheres and indigenous bacteria through a sandy aquifer: results of natural- and forced-gradient tracer experiments. Environ. Sci. Technol., 23:51.

McKinley, J.P., and Colwell, F.S., 1996. Application of perfluorocarbon tracers to microbial sampling in subsurface environments using mud-rotary and air-rotary drilling techniques. J. Microbiol. Meth., 26:1-9.

Plank, T., Ludden, J.N., Escutia, C., et al., in press. Proc. ODP, Init. Repts., 185 [CDROM]. Available from: Ocean Drilling Program, Texas A\&M University, College Station TX 77845-9547, USA.

Russell, B.F., Phelps, T.J., Griffin, W.T., and Sargent, K.A., 1992. Procedures for sampling deep subsurface microbial communities in unconsolidated sediments. Groundwater Monitoring Rev., 12:96-104.

Senum, G.I., and Dietz, R.N., 1991. Perfluorocarbon tracer tagging of drilling muds for the assessment of sample contamination. In Fliermans, C.B., and Hazen,T.C. (Eds.), Proc. First Int. Symp. Microbiology of Deep Subsurface. Westinghouse Savannah River Co. Information Service Section Publications Group, 7-145.

Smith, D.C., Spivack, A.J, Fisk, M.R., Haveman, S.A., Staudigel, H. and ODP Leg 185 Shipboard Scientific Party, in press. Drilling-induced microbial contamination of deep-sea crust. Geomicrobiol. J. 


\section{APPENDIX A}

\section{Calibration of the Gas Chromatograph for Perfluorocarbon Tracer Analysis}

1. Dilute the perfluorocarbon tracer in methanol in the following dilution series:

Add $0.1 \mathrm{~mL}$ PFT to $0.9 \mathrm{~mL}$ of methanol $=10^{-1}$

Add $0.1 \mathrm{~mL}$ of the $10^{-1}$ dilution to $9.9 \mathrm{~mL}$ of methanol $=10^{-3}$

Add $0.1 \mathrm{~mL}$ of the $10^{-3}$ dilution to $9.9 \mathrm{~mL}$ of methanol $=10^{-5}$

Add $0.1 \mathrm{~mL}$ of the $10^{-5}$ dilution to $9.9 \mathrm{~mL}$ of methanol $=10^{-7}$

Add $0.1 \mathrm{~mL}$ of the $10^{-7}$ dilution to $9.9 \mathrm{~mL}$ of methanol $=10^{-9}$

2. Transfer $10 \mu \mathrm{L}$ of the $10^{-3}, 10^{-5}, 10^{-7}$, and $10^{-9}$ dilutions into duplicate 20 -mL-capacity headspace vials and seal.

3. Heat vials and gas-tight syringes $\left(70^{\circ} \mathrm{C}\right)$.

4. Inject either 5.0 or $0.5 \mathrm{~mL}$ from each vial into the gas chromatograph.

5. Integrate the peak area for each injection and plot peak area against PFT(g) and perform a regression analysis to determine the slope. Table AT1 was constructed assuming the headspace vial capacity is $20 \mathrm{~mL}$ and the density of the PFT is $1.76 \mathrm{~g} / \mathrm{mL}$ using the formula

$\operatorname{PFT}(\mathrm{g})=($ volume added $)($ dilution $)($ density $)($ fraction of headspace injected $)$.

Example: (5.0 $\mathrm{mL}$ of the $10^{-7}$ dilution)

$$
\begin{aligned}
\operatorname{PFT}(\mathrm{g}) & =\left(10 \times 10^{-6} \mathrm{~L}\right)\left(10^{-7}\right)\left(\frac{1.76 \times 10^{3} \mathrm{~g}}{\mathrm{~L}}\right)\left(\frac{5.0 \times 10^{-3} \mathrm{~L}}{20.0 \times 10^{-3} \mathrm{~L}}\right) \\
& =4.4 \times 10^{-11} \mathrm{~g} \text { PFT }
\end{aligned}
$$

AT1. Method of calibrating the gas chromatograph, p. 19. 
D.C. SMITH ET AL.

Tracer Tests for Microbiological STUdies

\section{APPENDIX B}

\section{Calculations for Determining the Amount of Drill-Water Intrusion}

Use the following equations to determine the amount of drill-water intrusion in a sample:

$$
\frac{\text { drill water }(\mathrm{L})}{\text { core material }(\mathrm{g})}=\frac{\left(\mathrm{P}_{\mathrm{S}}-\mathrm{P}_{\mathrm{B}}\right)}{\left(\mathrm{C}_{\mathrm{DW}}\right)(\mathrm{a})(\mathrm{W})\left(\mathrm{F}_{\mathrm{I}}\right)} \text {, }
$$

where

$\mathrm{P}_{\mathrm{S}} \quad=$ integrated peak area of PFT in sample (in arbitrary units),

$P_{B} \quad=$ integrated peak area of PFT in blank (in arbitrary units),

$\mathrm{a}=$ slope derived from the calibration curve (in arbitrary units per gram),

$C_{D W}=$ concentration of PFT in drilling fluid (in grams per liter),

$\mathrm{W}=$ weight of sample (in grams), and

$\mathrm{F}_{\mathrm{I}}=$ fraction of the total headspace gas injected

$$
=\frac{\mathrm{V}_{\text {inj }}}{\mathrm{V}_{\text {vial }}-\left(\frac{\mathrm{W}}{\rho_{\text {bulk }}}\right)},
$$

where

$V_{\text {inj }}=$ volume of sample injected (in liters),

$\mathrm{V}_{\text {vial }}=$ volume of vial (in liters),

$\rho_{\text {bulk }}=$ sample density (in grams per liter), and

$\mathrm{W}=$ weight of sample (in grams).

Example:

$\mathrm{P}_{\mathrm{S}}=995$ arbitrary units

$P_{B}=566$ arbitrary units

$\mathrm{a}=1.1 \times 10^{13}$ arbitrary units $/ \mathrm{g}$ PFT

$\mathrm{C}_{\mathrm{DW}}=1 \mathrm{mg} / \mathrm{L}$

$\mathrm{W}=2.74 \mathrm{~g}$

$\mathrm{F}_{\mathrm{I}}=0.3$

$V_{\text {inj }}=5.0 \mathrm{~mL}$

$V_{\text {via }}=20 \mathrm{~mL}$

$\rho_{\text {bulk }}=1.5 \mathrm{~g} / \mathrm{cm}^{3}$

$=5.17 \times 10^{-8} \mathrm{~L} / \mathrm{g}$ 
D.C. SMITH ET AL.

Tracer Tests for Microbiological STUdies

\section{APPENDIX C}

The lower limit of detection of microspheres on the filters can be calculated by using the following equation:

$$
p=e^{\frac{-(\mathrm{x})(\mathrm{N})}{\mathrm{T}}},
$$

where

$$
\begin{aligned}
& p=\text { probability } \\
& \mathrm{x}=\text { number of microspheres, } \\
& \mathrm{T}=\text { number of fields of view counted, and } \\
& \mathrm{N}=\text { total number of fields of view on the filter. }
\end{aligned}
$$

Example:

The limit of detection at the 95\% confidence $(p=0.05)$ for counting 20 fields per filter, with 7100 fields of view per filter the limit of detection is

$$
=\frac{(7100)(\ln 0.05)}{-20}=1063 \text { microspheres. }
$$




\section{PUBLISHER'S NOTES}

Material in this publication may be copied without restraint for library, abstract service, education, or personal research purposes; however, republication of any portion requires the written consent of the Director, Ocean Drilling Program, Texas A\&M University, 1000 Discovery Drive, College Station TX 77845-9547, USA, as well as appropriate acknowledgment of this source. Reference to the whole or part of this report should be made as follows:

Smith, D.C., Spivack, A.J., Fisk, M.R., Haveman, S.A., Staudigel, H., and the Leg 185 Shipboard Scientific Party, 2000. Methods for quantifying potential microbial contamination during deep ocean coring. ODP Tech. Note, 28 [Online]. Available from World Wide Web: <http://www-odp.tamu.edu/publications/tnotes/ tn28/INDEX.HTM>. [Cited YYYY-MM-DD]

Electronic copies of this series may be obtained from the Ocean Drilling Program's World Wide Web site at http://www-odp.tamu.edu/publications

\section{DISCLAIMER}

This publication was prepared by the Ocean Drilling Program, Texas A\&M University, as an account of work performed under the international Ocean Drilling Program, which is managed by Joint Oceanographic Institutions, Inc., under contract with the National Science Foundation. Funding for the program is provided by the following agencies:

Australia/Canada/Chinese Taipei/Korea Consortium for Ocean Drilling

Deutsche Forschungsgemeinschaft (Federal Republic of Germany)

Institut National des Sciences de l'Univers-Centre National de la Recherche Scientifique (France)

Ocean Research Institute of the University of Tokyo (Japan)

National Science Foundation (United States)

Natural Environment Research Council (United Kingdom)

European Science Foundation Consortium for the Ocean Drilling Program (Belgium, Denmark, Finland, Iceland, Ireland, Italy, The Netherlands, Norway, Portugal, Spain, Sweden, and Switzerland)

Marine High-Technology Bureau of the State Science and Technology Commission of the People's Republic of China

Any opinions, findings, and conclusions or recommendations expressed in this publication are those of the author(s) and do not necessarily reflect the views of the National Science Foundation, the participating agencies, Joint Oceanographic Institutions, Inc., Texas A\&M University, or Texas A\&M Research Foundation. 
D.C. SMITH ET AL.

Tracer Tests for Microbiological Studies

Figure F1. Perfluorocarbon tracer delivery system located in the mud pump room of the JOIDES Resolution.

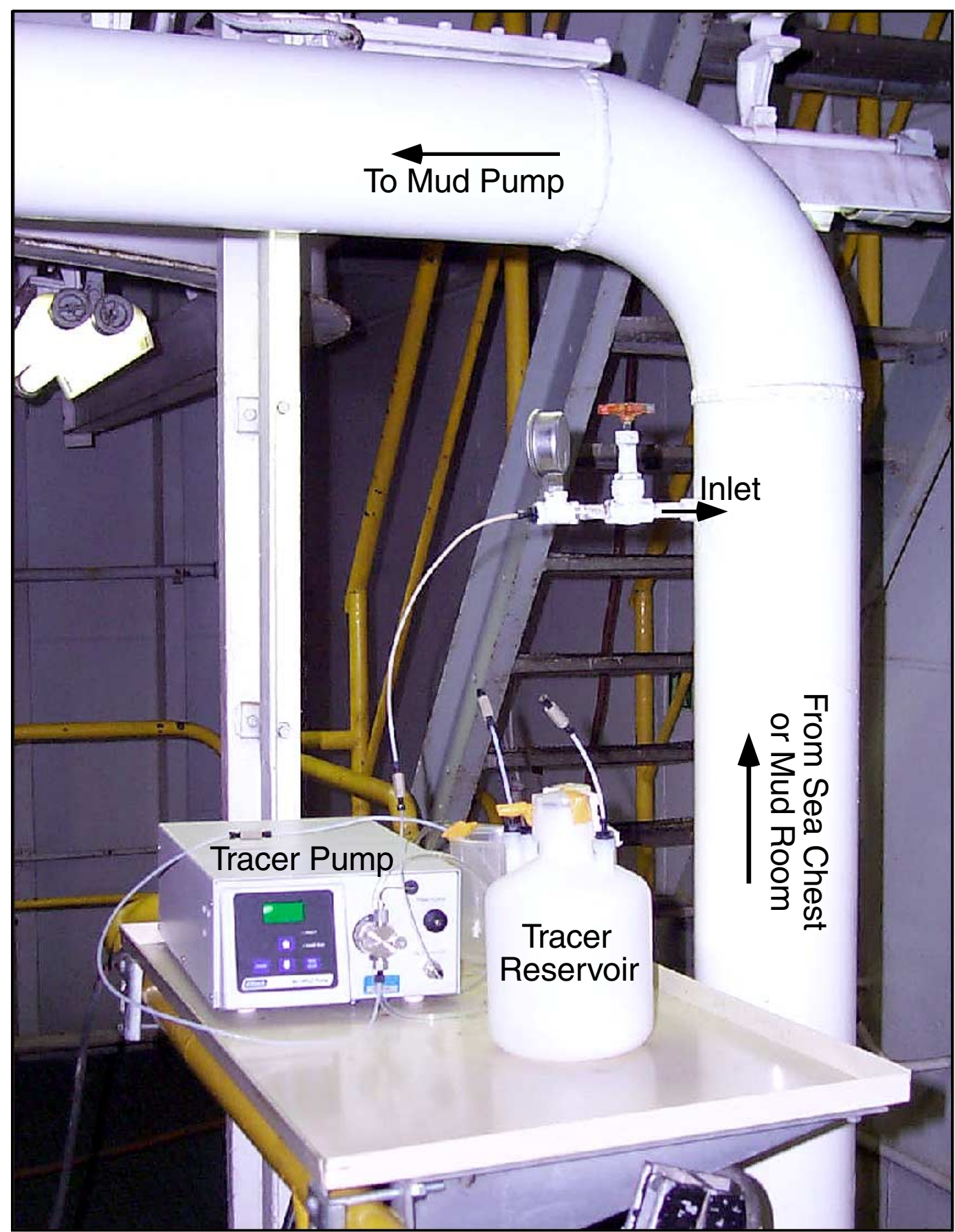


D.C. SMITH ET AL.

Tracer Tests For MiCrobiological STUdies

Figure F2. Calibration curve plotting peak area (arbitrary units) vs. quantity (in grams) for perfluoro(methylcyclohexane) injected into the gas chromatograph.

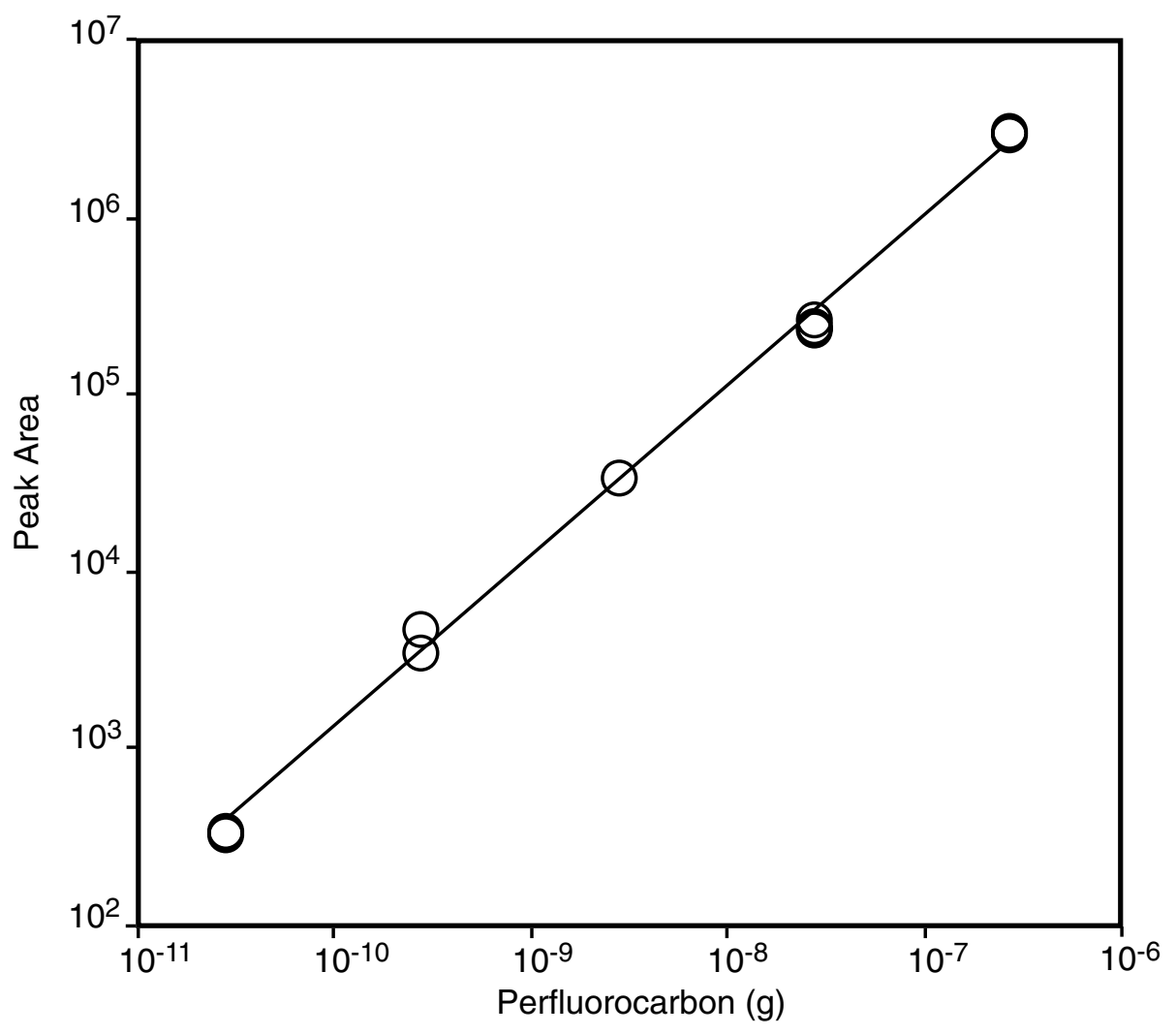


D.C. SMITH ET AL.

Tracer TeStS For Microbiological STUDIES

Figure F3. Surface seawater with stained bacteria (4',6-Diamidino-2-phenylindole) and 0.5- $\mu \mathrm{m}$ fluorescent microspheres viewed with epifluorescence microscopy (1250×).

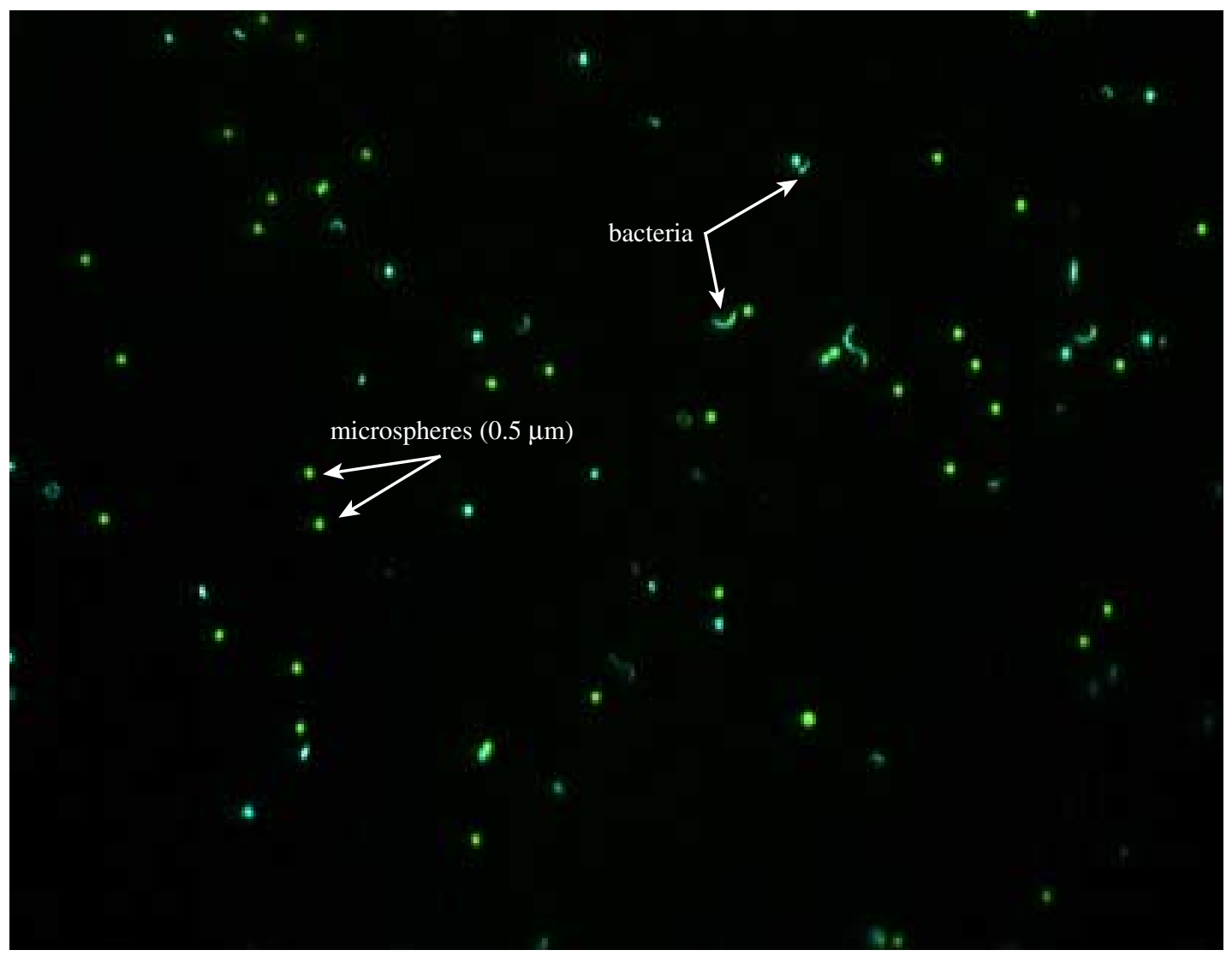


Figure F4. A. Spacer with a channel for the top of the Whirl-Pak bag containing the fluorescent microspheres. B. Bag containing $40 \mathrm{~mL}$ of the fluorescent microsphere suspension attached to the spacer. (Continued on next page.)

A

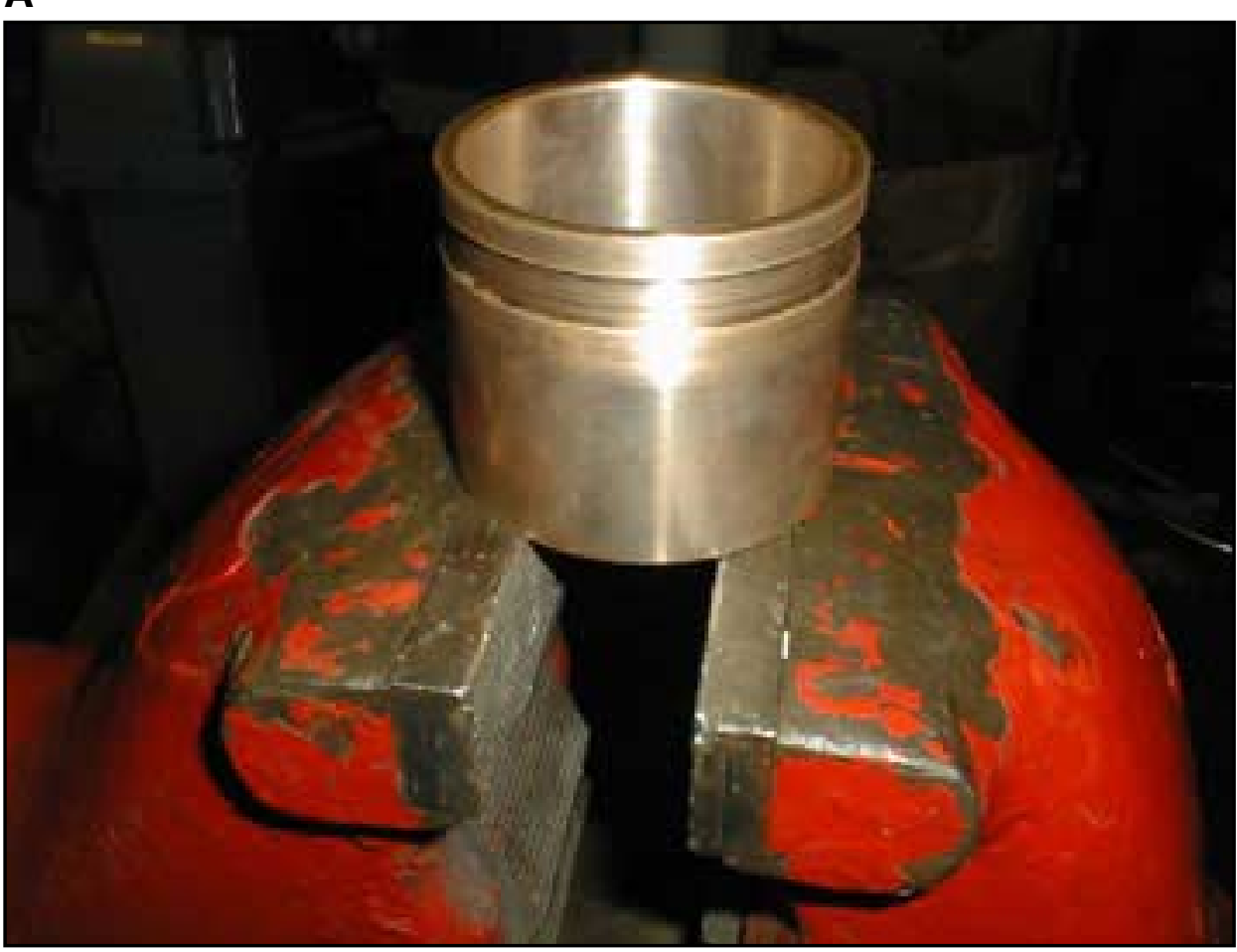

B

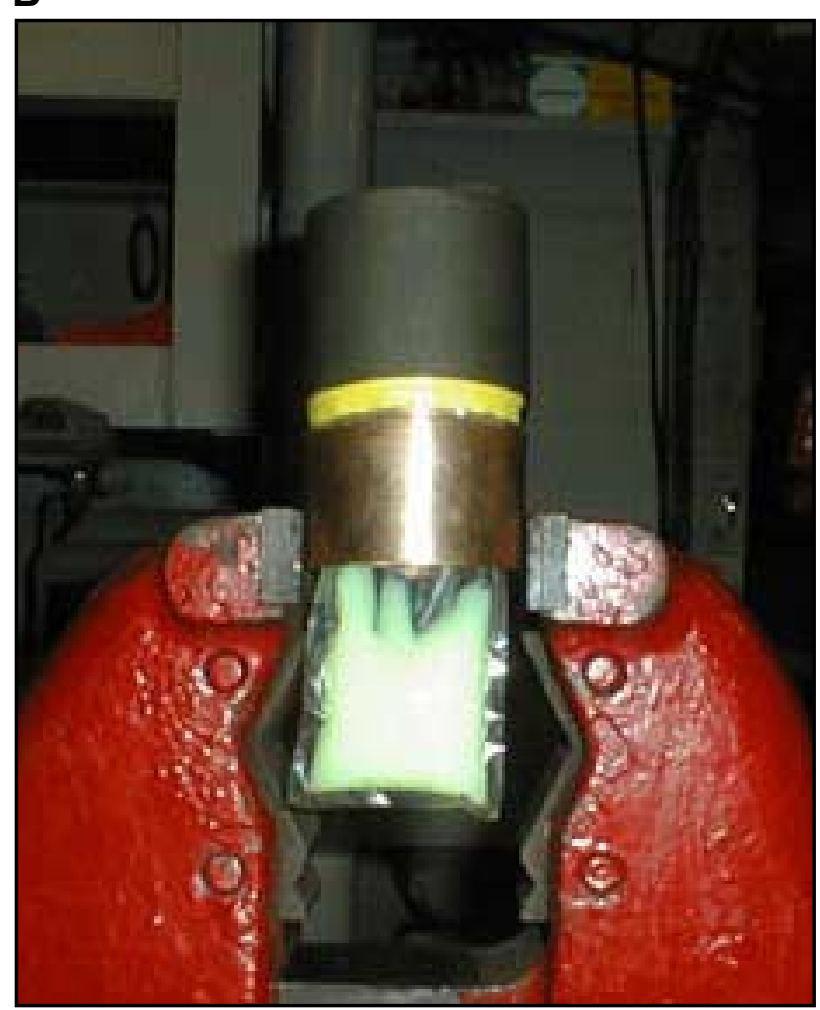


Figure F4 (continued). C. Bag containing microsphere suspension draped over the core-catcher body. D. The complete assembly for placing the microspheres in the core barrel. Top: petal flapper core catcher with metal sleeve. Middle: brass spacer with metal sleeve. Bottom: core-catcher body.

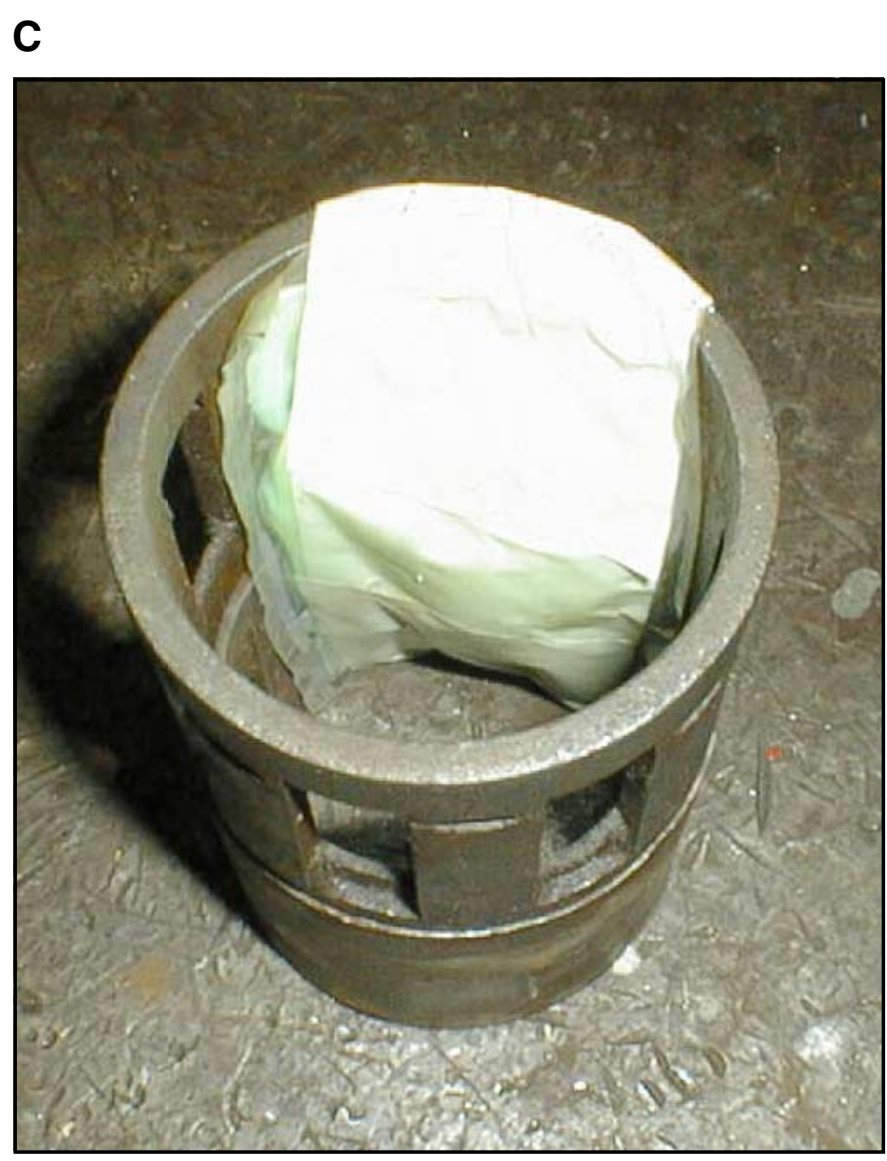

\section{D}

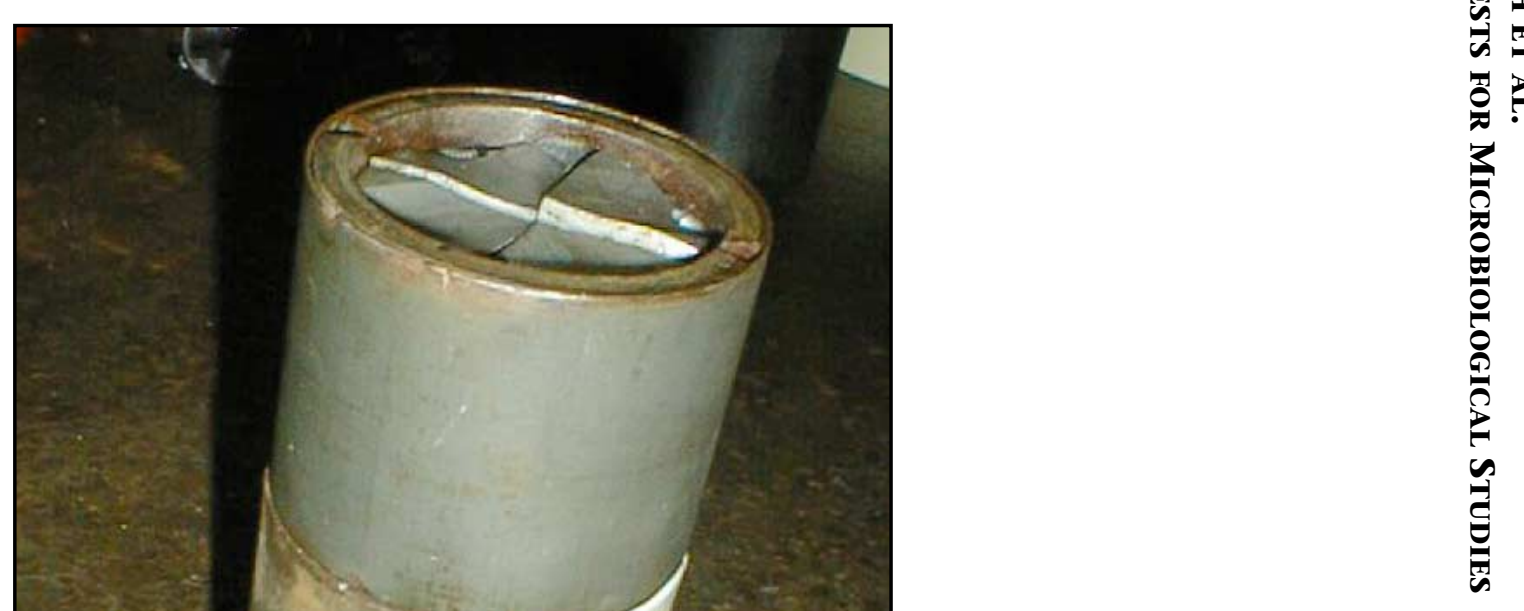


D.C. SMITH ET AL.

Tracer TeStS For MiCrobiological STUdies

Table T1. Chart used to calculate (1) travel time for PFT to drill bit based on mud pumping rate and length of drill string, and (2) HPLC pumping rate to maintain an $\sim 1 \mathrm{mg} / \mathrm{L}$ PFT solution in the drill string.

\begin{tabular}{|c|c|c|c|c|c|c|c|}
\hline \multirow[b]{2}{*}{$\begin{array}{l}\text { Strokes* } \\
\left(\min ^{-1}\right)\end{array}$} & \multirow[b]{2}{*}{$\begin{array}{c}\text { Liter } \\
\left(\min ^{-1}\right)\end{array}$} & \multirow{2}{*}{$\begin{array}{c}\text { HPLC } \\
\text { Pump } \\
\left.(\mathrm{mL} \mathrm{min})^{-1}\right)\end{array}$} & \multicolumn{5}{|c|}{ Time of PFT to drill bit with pipe length (m) } \\
\hline & & & $\begin{array}{l}5900 \\
(\min )\end{array}$ & $\begin{array}{l}6000 \\
(\mathrm{~min})\end{array}$ & $\begin{array}{l}6100 \\
(\min )\end{array}$ & $\begin{array}{l}6200 \\
(\min )\end{array}$ & $\begin{array}{l}6300 \\
(\mathrm{~min})\end{array}$ \\
\hline 5 & 98 & 0.05 & 602 & 612 & 622 & 633 & 643 \\
\hline 10 & 196 & 0.11 & 301 & 306 & 311 & 316 & 321 \\
\hline 15 & 294 & 0.16 & 201 & 204 & 207 & 211 & 214 \\
\hline 20 & 392 & 0.22 & 151 & 153 & 156 & 158 & 161 \\
\hline 25 & 490 & 0.27 & 120 & 122 & 124 & 127 & 129 \\
\hline 30 & 588 & 0.33 & 100 & 102 & 104 & 105 & 107 \\
\hline 35 & 686 & 0.38 & 86 & 87 & 89 & 90 & 92 \\
\hline 40 & 784 & 0.44 & 75 & 77 & 78 & 79 & 80 \\
\hline 45 & 882 & 0.49 & 67 & 68 & 69 & 70 & 71 \\
\hline 50 & 980 & 0.54 & 60 & 61 & 62 & 63 & 64 \\
\hline 55 & 1078 & 0.60 & 55 & 56 & 57 & 58 & 58 \\
\hline 60 & 1176 & 0.65 & 50 & 51 & 52 & 53 & 54 \\
\hline 65 & 1274 & 0.71 & 46 & 47 & 48 & 49 & 49 \\
\hline 70 & 1372 & 0.76 & 43 & 44 & 44 & 45 & 46 \\
\hline 75 & 1470 & 0.82 & 40 & 41 & 41 & 42 & 43 \\
\hline 80 & 1568 & 0.87 & 38 & 38 & 39 & 40 & 40 \\
\hline 85 & 1666 & 0.93 & 35 & 36 & 37 & 37 & 38 \\
\hline 90 & 1764 & 0.98 & 33 & 34 & 35 & 35 & 36 \\
\hline 95 & 1862 & 1.03 & 32 & 32 & 33 & 33 & 34 \\
\hline 100 & 1960 & 1.09 & 30 & 31 & 31 & 32 & 32 \\
\hline
\end{tabular}

Notes: PFT $=$ perfluorocarbon tracer; $\mathrm{HPLC}=$ high pressure liquid chromatography; ppm $=$ parts per million. ${ }^{*}=$ mud pump strokes were recorded on the rig floor. 1 stroke $=19.6 \mathrm{~L}$. 
D.C. SMith et AL.

Tracer Tests For MiCrobiological STUdies

Table AT1. Chart used to calculate the amount of PFT injected (in grams) based on the injection volume and the dilution of the standard.

\begin{tabular}{ccc}
\hline $\begin{array}{c}\text { Dilution } \\
\text { (vol:vol) }\end{array}$ & $\begin{array}{c}\text { Injection vol } \\
(\mathrm{mL})\end{array}$ & $\begin{array}{c}\text { Total PFT } \\
(\mathrm{g})\end{array}$ \\
\hline $10^{-9}$ & 5.0 & $4.4 \times 10^{-13}$ \\
$10^{-9}$ & 0.5 & $4.4 \times 10^{-12}$ \\
$10^{-7}$ & 5.0 & $4.4 \times 10^{-11}$ \\
$10^{-7}$ & 0.5 & $4.4 \times 10^{-10}$ \\
$10^{-5}$ & 5.0 & $4.4 \times 10^{-9}$ \\
$10^{-5}$ & 0.5 & $4.4 \times 10^{-8}$ \\
$10^{-3}$ & 5.0 & $4.4 \times 10^{-7}$ \\
$10^{-3}$ & 0.5 & $4.4 \times 10^{-6}$
\end{tabular}

Note: PFT = perfluorocarbon tracer. 